\title{
PENGARUH BAURAN PEMASARAN JASA TERHADAP KEPUTUSAN KONSUMEN MEMBELI PADA RUMAH MAKAN KHAS KAILI JALAN TEMBANG DI KOTA PALU
}

\author{
Pina \\ Zakiyah Zahara \\ Nirwan \\ Jurusan Manajemen, Fakultas Ekonomi, Universitas Tadulako \\ Email: finahusad@yahoo.co.id
}

\begin{abstract}
This research aims to know and analyze simultaneous and partial influence of service marketing mix $(X)$, which consist of product $(X 1)$, price $(X 2)$, place $(X 3)$, promotion $(X 4)$, people $(X 5)$, physical evidence (X6), and process (X7) on consumer decision (Y) to buy at the Kailinese restaurant in Palu. Based on the result of multiple linear regressions, it is shown that service marketing mix consist of product, price, place, promotion, people, physical evidence, and process, simultaneously have significant influence on consumer decision to buy at the Kailiniese restaurant in Palu with the sig. value of 0,737 or 73,7\%. Partially, the study also shown that service marketing mix which consist of product, price, place, promotion, people, physical evidence, and process have significant influence on consumer decision to buy at the Kailinese restaurant in Palu with the sig. value of product $=0,559$, price $=0,085$, place $=0,173$, promotion $=0,042$, people $=0,201$, physical evidence $=0,877$, and process $=0,000$. The most dominant variable that influences the decision of consumer is physical evidence.
\end{abstract}

Keywords: service marketing mix and consumer decision

\begin{abstract}
Abstrak
Penelitian ini bertujuan untuk mengetahui dan menganalisis pengaruh variabel bauran pemasaran jasa (X) yang terdiri dari produk (X1), harga (X2), tempat (X3), promosi (X4), orang (X5), bukti fisik (6), dan proses (X7), secara simultan dan parsial terhadap keputusan konsumen (Y) membeli di restoran khas Kaili Palu. Berdasarkan hasil regresi linier berganda, mendapatkan bahwa variabel bauran pemasaran jasa yang terdiri dari produk, harga, tempat, promosi, orang, bukti fisik, dan proses, secara bersamaan berpengaruh signifikan terhadap keputusan konsumen membeli di restoran kaili di Kota Palu. Dengan nilai pengaruh sebesar 0,737 atau 73,7\%. Variabel bauran pemasaran jasa yang terdiri dari produk, harga, tempat, promosi, orang, bukti fisik, dan proses secara parsial berpengaruh signifikan terhadap keputusan konsumen untuk membeli di restoran khas kaili di Kota Palu. Dengan nilai pengaruh sebesar: produk $=0559$, harga $=0085$, tempat $=0,173$, promosi $=$ $0,042,=0.201$ orang, bukti fisik $=0,877$, dan proses $=0,000$. variabel yang dominan mempengaruhi sebagian besar keputusan konsumen, variabel bukti fisik.
\end{abstract}

Kata Kunci: Bauran Pemasaran Jasa, Keputusan Konsumen

\section{PENDAHULUAN}

Kota Palu yang berada di Provinsi Sulawesi Tengah, merupakan pusat perekonomian, begitu banyak usaha yang berdiri baik dari usaha kecil sampai dengan usaha besar yang telah mempunyai nama dan dikenal oleh masyarakat kota Palu. Hal ini tentunya akan membuat kosumemen semakin selektif dalam menentukan pilihan pada rumah makan tertentu yang menjadi pilihan mereka, serta disisi lain persaingan antara sesama rumah makan akan semakin kompotitif.

Meskipun persaingan yang cukup ketat dan banyaknya pendatang baru membuka usaha yang sama serta permintaan konsumen yang selalu berubah-ubah dari waktu kewaktu, pengelola Rumah Makan Khas Kaili bernama Hj.Sarpiah yang berdiri sejak tahun 2004 ini cukup diminati masyarakat kota Palu karena menu yang disediakan sangat bervariasi seperti palumara, sayur kelor, nasi jangang, ikan bakar serta wempoy dan lain-lain.

Rumah makan ini terletak tidak jauh dari pantai Lere tepatnya di Jalan Tembang Kota Palu, kita bisa datang kesini mulai pukul 10 pagi hingga sore hari. Pemilik rumah makan berusaha memberikan 
kepuasan kepada konsumen dan memenuhui keinginan mereka melalui pemberian pelayanan yang sebaik-baiknya melalui penyajian menu yang beragam dan berkualias, harga yang sepandan dan memilihan lokasi rumah makan yang strategis.

Kombinasi dari variabel atau kegiatan yang merupakan inti dari pemasaran yang terdiri dari $7 \mathrm{P}$ yang berarti produk, harga, tempat, promosi, orang, bukti fisik, dan proses. Product (produk), yang ditawarkan pada Rumah Makan Khas Kaili ini berbagai macam menu seperti sayur kelor, sayur nangka, sayur uta dada, dan lain-lain. Pricing (harga), adalah sejumlah uang yang ditukar dengan produk yang terdapat pada menu suatu restoran atau rumah makan tersebut. Secara umum penetapan harga yang tepat dapat menarik perhatian pelanggan untuk melakukan keputusan pembelian pada Rumah Makan Khas Kaili. Place (tempat), mengingat mudahnya akses jalan untuk mencapai lokasi Rumah Makan Khas Kaili, Promotion (promosi), Rumah Makan Khas Kaili telah melakukan iklan disalah satu stasiun televisi yang ada dikota palu, People (orang), atau karyawan pada Rumah Makan Khas Kaili sangat ramah kepada semua pelanggan yang telah datang membeli masakan siap saji pada Rumah Makan Khas Kaili. Setiap karyawan mempunyai tugas masing-masing. Total 10 orang karyawan dan satu karyawan bagian kasir, Fhysical evidence (bukti fisik), Merupakan suatu hal yang secara nyata turut mempengaruhi keputusan konsumen untuk membeli produk, seperti desain dan tata ruang rumah makan yang menarik, tersedia sarana tempat parkir, dan kebersihan lingkungan rumah makan. Process (proses), yaitu merupakan salah satu kecepatan pelayanan yang tepat, agar konsumen tidak telalu lama menunggu pada saat proses melayani konsumen yang datang membeli pada Rumah Makan Khas Kaili.

Berdasarkan latar belakang di atas yang telah diuraikan, maka tujuan penelitian ini untuk mengetahui dan menganalisis

1. Pengaruh bauran pemasaran yang terdiri dari produk, harga, tempat, promosi, orang, bukti fisik, dan proses terhadap keputusan konsumen membeli pada Rumah Makan Khas Kaili di Kota Palu.

2. Pengaruh variabel produk terhadap keputusan konsumen membeli pada Rumah Makan Khas Kaili di Kota Palu.

3. Pengaruh variabel harga terhadap keputusan konsumen membeli pada Rumah Makan Khas Kaili di Kota Palu.

4. Pengaruh variabel tempat terhadap keputusan konsumen membeli pada Rumah Makan Khas Kaili di Kota Palu.

5. Pengaruh variabel promosi terhadap keputusan konsumen membeli pada Rumah Makan Khas Kaili di Kota Palu.

6. Pengaruh variabel orang terhadap keputusan konsumen membeli pada Rumah Makan Khas Kaili di Kota Palu.

7. Pengaruh variabel bukti fisik terhadap keputusan konsumen membeli pada Rumah Makan Khas Kaili di Kota Palu.

8. Pengaruh variabel proses terhadap keputusan konsumen pada Rumah Makan Khas Kaili di Kota Palu.

\section{KAJIAN LITERATUR DAN PENGEMBANGAN HIPOTESIS}

\section{Pengertian Pemasaran}

Menurut Kotler dan Keller (2009:5): bahwa pemasaran adalah sebuah proses kemasyarakatan dimana individu dan kelompok mendapat apa yang mereka butuhkan dan inginkan dengan menciptakan, menawarkan dan secara bebas mempertukarkan barang dan jasa yang bernilai dengan orang lain.

\section{Konsep Perilaku Konsumen}

Setiadi (2005:2): mengertikan perilaku konsumen sebagai tindakan yang langsung terlibat dalam mendapatkan, mengkonsumsi, dan menghabiskan produk atau jasa, termasuk proses keputusan yang mendahului dan menyusuli tindakan ini.

\section{Pengertian Jasa}

Jasa merupakan semua aktifitas ekonomi yang hasilnya bukan berbentuk fisik atau konstraksi, yang umumnya dihasilkan dan dikonsumsi secara bersama serta memberikan nilai tambah misalnya kenyamanan, hiburan, kesenangan, atau kesehatan konsumen. Menurut Lupiyoadi (2006;6): setiap 
tindakan atau kegiatan yang dapat ditawarkan oleh satu pihak kepada pihak lain, pada dasarnya tidak berwujut dan tidak mengakibatkan kepemilikan apapun.

\section{Bauran Pemasaran Jasa}

Bauran pemasaran (marketing mix) merupakan seperangakat alat yang dapat digunakan pemasar untuk membentuk karakteristik jasa yang ditawarkan kepada pelanggan. Alat-alat tersebut dapat digunakan pemasar untuk menyusun strategi jangaka panjang dan juga untuk merancang program taktik jangka pendek. Dengan demekian, unsur pengalaman, kompentensi, pengetahuan, dan kreativitas memainkan peranan penting dalam menunjang kesuksesan pemasaran.

\section{Proses pengambilan keputusan konsumen}

Keputusan pembelian yang dilakukan konsumen sangat bervariasi, ada yang sederhana dan komplek. Untuk lebih rincinya dapat dilihat pada dambar 1 berikut.

Sumber: Setiadi (2005:14)

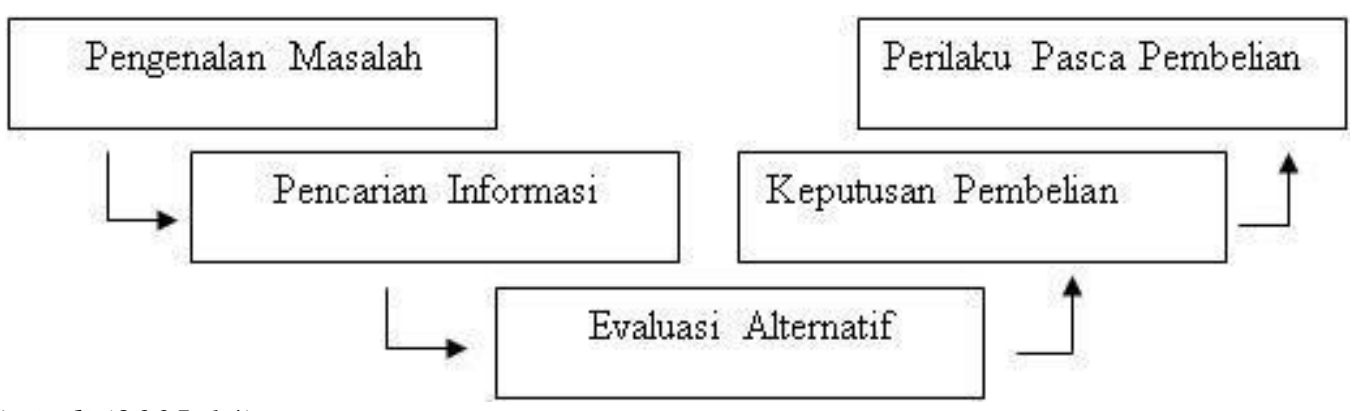

Gambar 1 Pengambilan Keputusan

\section{METODE PENELITIAN}

Adapun metode pengumpulan data yang digunakan dalam penelitian ini adalah observasi, wawancara, dan kuesioner. Populasi dalam penelitian ini adalah mencakup seluruh pengunjung yang telah melakukan pembelian makanan pada Rumah Makan Khas Kaili di Kota Palu. Karena tidak ada datanya atau catatan yang disediakan oleh pihak Rumah Makan, maka populasi dalam penelitian ini tidak di ketahui jumlahnya. Sampel yang digunakan dalam penelitian ini yaitu konsumen yang telah melakukan pembelian pada Rumah Makan Khas Kaili di Kota Palu. jumlah sampel ditentukan sebagai berikut:

$$
10(7+1)=10(8)=80 .
$$

Jadi jumlah sampel dalam penelitian ini adalah 80 responden.

Selanjutnya menurut Sugiyono (2010:277) analisis data yang sesuai dengan hipotesis yang diajukan adalah regresi linier berganda, dengan persamaan sebagai berikut:

$$
\mathrm{Y}=\mathrm{a}+\mathrm{b} 1 \mathrm{X} 1+\mathrm{b} 2 \mathrm{X} 2 \ldots \ldots \mathrm{bnXn}
$$

Di mana :

$\mathrm{Y} \quad=$ Variabel tak bebas (dependen variabel)

$\mathrm{a}=$ Konstanta (intercept)

$\mathrm{X} 1-\mathrm{Xn}=$ Variabel bebas (independen variabel)

b1-bn = Besaran yang akan digunakan (koefisien regresi

Apabila variabel dalam penelitian ini diaplikasikan ke dalam bentuk persamaan Regresi Linear berganda, maka diperoleh bentuk persamaan berikut ini:

$\mathrm{Y}=\mathrm{a}+\mathrm{b}_{1} \mathrm{X}_{1}+\mathrm{b}_{2} \mathrm{X}_{2}+\mathrm{b}_{3} \mathrm{X}_{3}+\mathrm{b}_{4} \mathrm{X}_{4}+\mathrm{b}_{5} \mathrm{X}_{5}+\mathrm{b}_{6} \mathrm{X}_{6}+\mathrm{b}_{7} \mathrm{X}_{7}$ 
Di mana:

$$
\begin{array}{ll}
\mathrm{Y} & =\text { Keputusan Konsumen } \\
\mathrm{X}_{1} & =\text { Produk } \\
\mathrm{X}_{2} & =\text { Harga } \\
\mathrm{X}_{3} & =\text { Tempat } \\
\mathrm{X}_{4} & =\text { Promosi } \\
\mathrm{X}_{5} & =\text { Orang } \\
\mathrm{X}_{6} & =\text { Proses } \\
\mathrm{X}_{7} & =\text { Bukti fisik } \\
\mathrm{a} & =\text { Konstanta / intercept } \\
\mathrm{b}_{1}-\mathrm{b}_{7} & =\text { Koefisien Regresi }
\end{array}
$$

\section{HASIL DAN PEMBAHASAN}

\section{Hasil Penelitian}

Regresi linear berganda dilakukan untuk menganalisis dan menerangkan keterkaitan hubungan dan pengaruh antara dua atau lebih dari variabel penelitian yang berbeda nama melalui pengamatan.

Tabel 1 Hasil Uji Regresi Linear Berganda

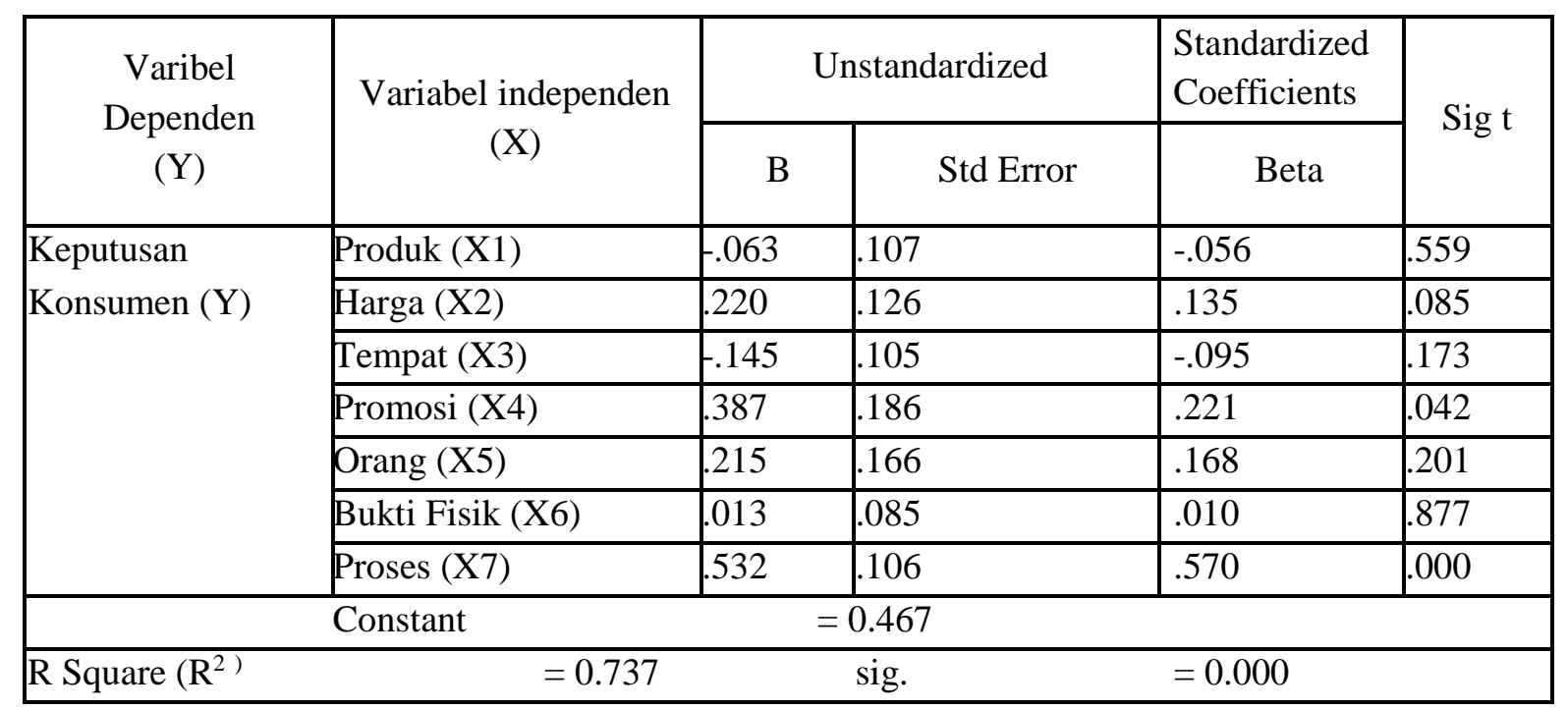

Hasil analisis linaer berganda dari tabel di atas kemudia dimasukan kedalam model persamaan regresi linear berganda sebagai berikut:

$\mathrm{Y}=0.467+(-0.063 \mathrm{X} 1)+0.220 \mathrm{X} 2+(-0.145 \mathrm{X} 3)+0.387 \mathrm{X} 4+0.215 \mathrm{X} 5+0.013 \mathrm{X} 6+0.532 \mathrm{X} 7$

a. Nilai konstanta $\alpha$ adalah 0,467 yang menunjukan bahwa bauran pemasaran yang terdiri dari variabel produk $\left(\mathrm{X}_{1}\right)$, harga $\left(\mathrm{X}_{2}\right)$, tempat $\left(\mathrm{X}_{3}\right)$, promosi $\left(\mathrm{X}_{4}\right)$ orang $\left(\mathrm{X}_{5}\right)$, bukti fisik $\left(\mathrm{X}_{6}\right)$, proses $\left(\mathrm{X}_{7}\right)$ meningkat sebesar 0,467 akan menyebabkan pemimgkatan terhadap keputusan konsumen.

b. Nilai koefisien regresi $b_{1}$ adalah $(-0,063)$ yang menunjukan bahwa variabel produk $\left(\mathrm{X}_{1}\right)$ adalah arah pengaruhnya positif terhadap keputusan konsumen. Berarti jika produk meningkat sebesar (0,063 ) maka akan menyebabkan peningkatan terhadap keputusan konsumen.

c. Nilai koefisien regresi $b_{2}$ adalah 0,220 yang menunjukan bahwa variabel harga $\left(X_{2}\right)$ adalah arah pengaruhnya positif terhadap keputusan konsumen. Berarti jika harga meningkat sebesar 0,220 maka akan menyebabkan peningkatan terhadap keputusan konsumen. 
d. Nilai koefisien regresi $b_{3}$ adalah $(-0,145)$ yang menunjukan bahwa variabel tempat $\left(\mathrm{X}_{3}\right)$ adalah arah pengaruhnya negatif terhadap keputusan konsumen. Berarti jika tempat meningkat sebesar $(-0,145)$ maka akan menyebabkan penurunan terhadap keputusan konsumen.

e. Nilai koefisien regresi $\mathrm{b}_{4}$ adalah 0,387 yang menunjukan bahwa variabel promosi $\left(\mathrm{X}_{4}\right)$ adalah arah pengaruhnya positif terhadap keputusan konsumen. Berarti jika promosi meningkat sebesar 0,387 maka akan menyebabkan peningkatan terhadap keputusan konsumen.

f. Nilai koefisien regresi $b_{5}$ adalah 0,215 yang menunjukan bahwa variabel orang $\left(X_{5}\right)$ adalah arah pengaruhnya positif terhadap keputusan konsumen. Berarti jika orang meningkat sebesar 0,215 maka akan menyebabkan peningkatan terhadap keputusan konsumen.

g. Nilai koefisien regresi $b_{6}$ adalah 0,013 yang menunjukan bahwa variabel bukti fisik $\left(\mathrm{X}_{6}\right)$ adalah arah pengaruhnya positif terhadap keputusan konsumen. Berarti jika bukti fisik meningkat sebesar 0,013 maka akan menyebabkan peningkatan terhadap keputusan konsumen.

h. Nilai koefisien regresi $b_{7}$ adalah 0,532 yang menunjukan bahwa variabel proses $\left(X_{7}\right)$ adalah arah pengaruhnya positif terhadap keputusan konsumen. Berarti jika proses meningkat sebesar 0,532 maka akan menyebabkan peningkatan terhadap keputusan konsumen.

\section{Pengujian Hipotesis Pertama (Uji F)}

Berdasarkan hasil pengujian yang telah dilakukan seperti yang dilihat pada tabel rekapitulasi analisis Regresi Linear Berganda di atas dapat lihat bahwa nilai hasil pengujian sig F atau probabilitas adalah 0.000 . Nilai sig F yang diperoleh $<\alpha=0.05$. Dengan demikian dapat ditarik kesimpulan bahwa variabel bauran pemasaran jasa yang terdiri dari produk, harga, tempat, promosi, orang, bukti fisik, dan proses secara serempak berpengaruh signifikan terhadap keputusan konsumen membeli pada Rumah Makan Khas Kaili Jalan Tembang di Kota Palu. Dengan besar pengaruh R Square $\left(\mathrm{R}^{2}\right)$ sebesar 0.737 atau $73.7 \%$. Adapun sisanya $(26,3 \%)$ dipengaruhi oleh sebab-sebab diluar dari variabel penelitian ini atau dapat dijelaskan oleh faktor lain.

\section{Pengujian Hipotesis Kedua Sampai Kedelapan (Uji T)}

Adapun nilai determinasi parsial setiap variabel independen terhadap variabel dependen adalah sebagai berikut:

Variabel Produk $\left(\mathbf{X}_{\mathbf{1}}\right)$. Hasil analisis data yang telah dilakukan dan telah dipaparkan pada tabel rekapitulasi hasil analisis Regresi Linear Berganda pada tabel 1, hal ini terbukti dengan melihat nilai sig t variabel produk $\left(\mathrm{X}_{1}\right)$ yaitu sebesar 0.559. Bila dibandingkan dengan $\alpha=0.05$, maka sig $\mathrm{t}(0.559)$ $>\alpha(0.05)$. Melihat hasil perbandingan tersebut maka dapat disimpulkan bahwa variabel produk tidak berpengaruh signifikan terhadap keputusan konsumen dengan kontribusi pengaruh sebesar -0,056 atau 5,60\%. Dengan kata lain bahwa hipotesis kedua yang diajukan ditolak kebenarannya.

Variable Harga $\left(\mathbf{X}_{2}\right)$. H Berganda pada tabel 1, hal ini terbukti dengan melihat nilai sig t variabel harga $\left(\mathrm{X}_{2}\right)$ yaitu sebesar 0.085. Bila dibandingkan dengan $\alpha=0.05$, maka sig t $(0.085)>\alpha(0.05)$. Melihat hasil perbandingan tersebut maka dapat disimpulkan bahwa variabel harga tidak berpengaruh signifikan terhadap keputusan konsumen dengan kontribusi pengaruh sebesar 0,135 atau 13,50\%. Dengan kata lain bahwa hipotesis kedua yang diajukan ditolak kebenarannya.

Variabel Tempat $\left(\mathbf{X}_{\mathbf{3}}\right)$. Hasil analisis data yang telah dilakukan dan telah dipaparkan pada tabel hasil analisis Regresi Linear Berganda pada tabel 5.16, hal ini terbukti dengan melihat nilai sig t variabel tempat $\left(\mathrm{X}_{3}\right)$ yaitu sebesar 0.173 . Bila dibandingkan dengan $\alpha=0.05$, maka sig t $(0173)>\alpha$ (0.05). Melihat hasil perbandingan tersebut maka dapat disimpulkan bahwa variabel tempat tidak berpengaruh signifikan terhadap keputusan konsumen dengan kontribusi pengaruh sebesar -0,095 atau 9,50\%. Dengan kata lain bahwa hipotesis kedua yang diajukan ditolak kebenarannya.

Variabel Promosi $\left(\mathbf{X}_{4}\right)$. Hasil analisis data yang telah dilakukan dan telah dipaparkan pada tabel hasil analisis Regresi Linear Berganda pada tabel 5.16, hal ini terbukti dengan melihat nilai sig t variabel promosi $\left(\mathrm{X}_{4}\right)$ yaitu sebesar 0.042. Bila dibandingkan dengan $\alpha=0.05$, maka sig $\mathrm{t}(0.042)<\alpha$ 
(0.05). Melihat hasil perbandingan tersebut maka dapat disimpulkan bahwa variabel promosi berpengaruh signifikan terhadap keputusan konsumen dengan kontribusi pengaruh sebesar 0.221 atau $22,10 \%$. Dengan kata lain bahwa hipotesis yang diajukan diterima kebenarannya.

Variabel Orang $\left(\mathbf{X}_{\mathbf{5}}\right)$. Hasil analisis data yang telah dilakukan dan telah dipaparkan pada tabel hasil analisis Regresi Linear Berganda pada tabel 5.16, hal ini terbukti dengan melihat nilai sig t variabel orang $\left(\mathrm{X}_{5}\right)$ yaitu sebesar 0.201. Bila dibandingkan dengan $\alpha=0.05$, maka sig t $(0.201)>\alpha$ (0.05). Melihat hasil perbandingan tersebut maka dapat disimpulkan bahwa variabel orang tidak berpengaruh signifikan terhadap keputusan konsumen dengan kontribusi pengaruh sebesar 0,168 atau $16,80 \%$. Dengan kata lain bahwa hipotesis yang diajukan ditolak kebenarannya.

Variabel Bukti Fisik $\left(\mathbf{X}_{6}\right)$. Hasil analisis data yang telah dilakukan dan telah dipaparkan pada tabel hasil analisis Regresi Linear Berganda pada tabel 5.16, hal ini terbukti dengan melihat nilai sig t variabel bukti fisik $\left(\mathrm{X}_{5}\right)$ yaitu sebesar 0.877 . Bila dibandingkan dengan $\alpha=0.05$, maka sig t $(0.877)>$ $\alpha(0.05)$. Melihat hasil perbandingan tersebut maka dapat disimpulkan bahwa variabel bukti fisik tidak berpenharuh signifikan terhadap keputusan konsumen dengan kontribusi pengaruh sebesar 0,010 atau $1,00 \%$. Dengan kata lain bahwa hipotesis yang diajukan ditolak kebenarannya.

Variabel Proses $\left(\mathbf{X}_{7}\right)$. Dari hasil analisis data yang telah dilakukan dan telah dipaparkan pada tabel hasil analisis Regresi Linear Berganda pada tabel 5.16, hal ini terbukti dengan melihat nilai sig t variabel proses $\left(\mathrm{X}_{5}\right)$ yaitu sebesar 0.000 . Bila dibandingkan dengan $\alpha=0.05$, maka sig $\mathrm{t}(0.000)<\alpha$ (0.05). Melihat hasil perbandingan tersebut maka dapat disimpulkan bahwa variabel proses berpengaruh signifikan terhadap keputusan konsumen dengan kontribusi pengaruh sebesar 0,570 atau $57,00 \%$. Dengan kata lain bahwa hipotesis yang diajukan diterima kebenarannya.

\section{Pembahasan}

\section{Pengaruh Variabel Produk $\left(\mathbf{X}_{1}\right)$}

Variabel produk $\left(\mathrm{X}_{1}\right)$ merupakan variabel yang berpengaruh tapi tidak signifikan terhadap keputusan konsumen pada rumah makan khas kaili jalan tembang di kota palu. Selanjutnya sesuai dengan hasil penelitian di lapangan terhadap keputusan konsumen pada rumah makan khas kaili jalan tembang di kota palu, dari 4 item indikator pernyataan variabel produk, yaitu 1) lezat, 2) tradisional,

3) variasi menu kesemuanya memberikan pengaruh tapi tidak signifikan terhadap keputusan konsumen pada rumah makan khas kaili jalan tembang di kota palu.

\section{Pengaruh Variabel harga $\left(\mathbf{X}_{2}\right)$}

Variabel harga $\left(\mathrm{X}_{2}\right)$ merupakan variabel yang berpengaruh tapi tidak signifikan terhadap keputusan konsumen pada rumah makan khas kaili jalan tembang di kota palu. Selanjutnya sesuai dengan hasil penelitian di lapangan terhadap keputusan konsumen pada rumah makan khas kaili jalan tembang di kota palu, dari 3 item indicator pernyataan variabel harga, yaitu 1) harga yang terjangkau, 2) harga bersaing, 3) harga sesuia makanan kesemuanya memberikan pengaruh tapi tidak signifikan terhadap keputusan konsumen pada rumah makan khas kaili jalan tembang di kota palu.

\section{Pengaruh Variabel Tempat $\left(\mathbf{X}_{3}\right)$}

Variabel tempat $\left(\mathrm{X}_{3}\right)$ merupakan variabel yang berpengaruh tapi tidak signifikan terhadap keputusan konsumen pada rumah makan khas kaili jalan tembang di kota palu. Selanjutnya sesuai dengan hasil penelitian di lapangan terhadap keputusan konsumen pada rumah makan khas kaili jalan tembang di kota palu, dari 3 item indicator pernyataan variabel tempat, yaitu 1) mudah dijangkau, 2) tempat parkir, dan 3) lokasih trategis kesemuanya memberikan pengaruh tapi tidak signifikan terhadap keputusan konsumen pada rumah makan khas kaili jalan tembang di kota palu.

\section{Pengaruh Variabel Promosi $\left(\mathbf{X}_{4}\right)$}

Variabel romosi $\left(\mathrm{X}_{4}\right)$ merupakan variabel yang berpengaruh tapi tidak signifikan terhadap keputusan konsumen pada rumah makan khas kaili jalan tembang di kota palu. Selanjutnya sesuai 
dengan hasil penelitian di lapangan terhadap keputusan konsumen pada rumah makan khas kaili jalan tembang di kota palu, dari 3 item indikator pernyataan variabel promosi, yaitu 1) iklan media massa (televisi lokal global), 2) of the muoth, dan 3) spanduk memberikan pengaruh signifikan terhadap keputusan konsumen pada rumah makan khas kaili jalan tembang di kota. Dalam arti, bahwa variabel orang memiliki pengaruh yang signifikan terhadap keputusan konsumen pada rumah makan khas kaili jalan tembang di kota palu.

\section{Pengaruh Variabel Orang $\left(\mathbf{X}_{5}\right)$}

Variabel orang $\left(\mathrm{X}_{5}\right)$ merupakan variabel yang berpengaruh tapi tidak signifikan terhadap keputusan konsumen pada rumah makan khas kaili jalan tembang di kota palu. Selanjutnya sesuai dengan hasil penelitian di lapangan terhadap keputusan konsumen pada rumah makan khas kaili jalan tembang di kota palu, dari 4 item indikator pernyataan variabel orang yaitu,1), cepat 2) ramah, 3) rapi ,dan 4) teliti memberikan pengaruh signifikan terhadap keputusan konsumen pada rumah makan khas kaili jalan tembang di kota. Dalam arti, bahwa variabel orang memiliki pengaruh tapi tidak signifikan terhadap keputusan konsumen.

\section{Pengaruh Variabel Bukti Fisik $\left(\mathbf{X}_{6}\right)$}

Variabel bukti fisik $\left(\mathrm{X}_{6}\right)$ merupakan variabel yang berpengaruh tapi tidak signifikan terhadap keputusan konsumen pada rumah makan khas kaili jalan tembang di kota palu. Selanjutnya sesuai dengan hasil penelitian di lapangan terhadap keputusan konsumen pada rumah makan khas kaili jalan tembang di kota palu, dari 4 item indikator pernyataan variabel bukti fisik yaitu,1), kebersihan ruangan2) kebersihan Wc, 3) kebersihan meja ,dan 4) kebersihan dapur memberikan pengaruh signifikan terhadap keputusan konsumen pada rumah makan khas kaili jalan tembang di kota. Dalam arti, bahwa variabel bukti fisik memiliki pengaruh tapi tidak signifikan terhadap keputusan konsumen.

\section{Perngaruh Variabel Proses $\left(\mathbf{X}_{7}\right)$}

Variabel proses $\left(\mathrm{X}_{7}\right)$ merupakan variabel yang berpengaruh tapi tidak signifikan terhadap keputusan konsumen pada rumah makan khas kaili jalan tembang di kota palu. Selanjutnya sesuai dengan hasil penelitian di lapangan terhadap keputusan konsumen pada rumah makan khas kaili jalan tembang di kota palu, dari 5 item indikator pernyataan variabel proses yaitu, 1), kesesuaian pesanan 2) tepat dalam pembataran, 3) cepat dalam melayani, 4) cepat dalam proses pembayaran, dan 5) penyajian yang cepat memberikan pengaruh signifikan terhadap keputusan konsumen pada rumah makan khas kaili jalan tembang di kota. Dalam arti, bahwa variabel proses memiliki pengaruh signifikan terhadap keputusan konsumen pada rumah makan khas kaili di Kota Palu.

\section{KESIMPULAN DAN SARAN}

\section{Kesimpulan}

1. Berdasarkani ketuju demensi dalam variabel independen keputusan konsumen yang terdiri dari Produk $\left(\mathrm{X}_{1}\right)$, Harga $\left(\mathrm{X}_{2}\right)$, Tempat $\left(\mathrm{X}_{3}\right)$, Promosi $\left(\mathrm{X}_{4}\right)$, Orang $\left(\mathrm{X}_{5}\right)$, Bukti fisik $\left(\mathrm{X}_{6}\right)$, dan Proses $\left(\mathrm{X}_{7}\right)$. Secara simultan hanya ada dua variabel yang berpengaruh signifikan terhadap keputusan konsumen membeli pada rumah makan khas kaili jalan tembang di Kota Palu

2. Variabel produk $\left(\mathrm{X}_{1}\right)$ secara parsial tidak berpengaruh signifikan terhadap keputusan konsumen membeli pada rumah makan khas kaili jalan tembang di Kota Palu.

3. Variabel harga $\left(\mathrm{X}_{2}\right)$ secara parsial tidak berpengaruh signifikan terhadap keputusan konsumen membeli pada rumah makan khas kaili jalan tembang di Kota Palu.

4. Variabel tempat $\left(\mathrm{X}_{3}\right)$ secara parsial tidak berpengaruh signifikan terhadap keputusan konsumen membeli pada rumah makan khas kaili jalan tembang di Kota Palu.

5. Variabel promosi $\left(\mathrm{X}_{4}\right)$ secara parsial berpengaruh signifikan terhadap keputusan konsumen membeli pada rumah makan khas kaili jalan tembang di Kota Palu. 
6. Variabel orang $\left(\mathrm{X}_{5}\right)$ secara parsial tidak berpengaruh signifikan terhadap keputusan konsumen membeli pada rumah makan khas kaili jalan tembang di Kota Palu.

7. Variabel bukti fisik $\left(\mathrm{X}_{6}\right)$ secara parsial tidak berpengaruh signifikan terhadap keputusan konsumen membeli pada rumah makan khas kaili jalan tembang di Kota Palu.

8. Variabel proses $\left(\mathrm{X}_{7}\right)$ secara parsial berpengaruh signifikan terhadap keputusan konsumen membeli pada rumah makan khas kaili jalan tembang di Kota Palu.

\section{Saran}

1. Khusus pemilik rumah makan khas kaili sebaiknya terus mempertahankan ataupun menambahkan demensi-demensi yang lebih beragam lagi agar rasa emosional yang dialami oleh konsumen pada saat atau setelah konsumen melakukan pembelian. Perasaan atau emosi ini akan berupa rasa senang karena produk yang dibeli sesuai dengan yang diinginkan dan tetap bisa memuaskan pelanggan.

2. Untuk peneliti selanjutnya, diharapakan untuk mencari atau menambahkan variabel-variabel yang rendah dengan indikator-indikator yang lainnnya, dan bisa membentuk keputusan konsumen yang telah melakukan pembelian pada rumah makan khas kaili jalan tembang di Kota Palu.

\section{REFERENSI}

Kotler Philip Dan Kevin Lane Keller. (2009). Marketing management. $14^{\text {th }}$ edition, Pearson France. Lupiyoadi, R. (2006). Manajmen Pemasaran Jasa (Teori dan Praktik). Jakarta: Salemba 4.

Malholtra, Naresh K. (2005). Riset pemasaran, Edisi Keempat, Jilid II, Jakarta: Indeks Kelompok Gramedia.

Setiadi, Nugroho J. (2005). Perilaku Konsumen (Konsep dan Implikasi Untuk Strategi dan Penelitian Pemasaran). Jakarta: Prenada Media.

Solimun. (2005). Multivariate Analisis Structural Eguation Modeling (SEM). Malang: Universitas Negeri Malang.

Sugiyono. (2010). Metode Penelitian Bisnis. Penerbit Cetakan ke-17. Bandung: Alfabeta. 